\title{
Cosmogonic Sacrifice
}

\section{A Ghost Zoroastrian Doctrine}

\author{
Amir Ahmadi* \\ Monash University \\ amir.ahmadi@monash.edu
}

\begin{abstract}
A number of prominent scholars of Zoroastrianism have recently taken up Marijan Molé's thesis that Ahura Mazdā created the world by way of a sacrifice. This article examines the sources that have been adduced for the thesis. It concludes that neither in Avestan nor Pahlavi texts do we find any evidence for the supposed cosmogonic sacrifice.
\end{abstract}

\section{Keywords}

Zoroastrianism - sacrifice - cosmogony - Avesta

The view that Ahura Mazdā created the world by way of a sacrifice is becoming the new orthodoxy of the scholarship on Zoroastrian cosmology and ritual. It was first formulated by Marijan Molé in his monumental work on Zoroastrian ritual and cosmology (1963), which he called 'la doctrine mazdéenne du sacrifice.' It has been taken up with the delay of a few decades by a number of prominent and prolific scholars of the Avesta. The setting for the reception of Molé's 'doctrine' is the awareness of the central importance of ritual in Zoroastrianism, which has been growing steadily since the 1990s. This realization naturally placed the question of the function(s) of Zoroastrian ritual(s) on the scholar's agenda. Indeed, one may plausibly talk of a paradigm shift in the study of Zoroastrianism, from the Biblical model to the Vedic model.

\footnotetext{
* I am grateful to the reviewers for their helpful comments which have improved this article.

1 Marijan Molé (1963), 125.
} 
In his inaugural lecture at the Collège de France in April 1994, Kellens programmatically announced the new paradigm. The Avesta must be placed in Vedic horizon, not just linguistically but also ideologically. 'Je crois le temps venu d'un retour à la méthode védisante pure et dure pour éclairer le texte de l'Avesta et le texte dans son ensemble, c' est-à-dire non seulement sa langue, mais aussi les conceptions religieuses qui s'y expriment.'2 The ritualist turn has produced significant and lasting results. The past decade especially has seen the appearance of a number of important studies of Zoroastrian liturgy in historical, philological and ideological perspectives. But the new optics has also had its blind spots. The reception of Molés doctrine of cosmogonic sacrifice has been precipitous, without due care and examination of the sources. In his recent publications, Cantera uses the term 'cosmogonic sacrifice' of the primordial recitation of the ahuna vairiia without further ado. ${ }^{3}$ Below I would like to examine the texts that have been cited as evidence by Molé, Skjærvø and Kellens in support of the idea of cosmogonic sacrifice in Zoroastrianism.

According to Molé, every Zoroastrian ritual repeats Ahura Mazdā's cosmogonic sacrifice and hence partakes of its organizing power, while it is also an anticipation of the final sacrifice by which the creator god restores the world to its pristine state. '[L]e sacrifice est une repetition de l' acte par lequel le monde fut crée. Le vrai sacrificateur ... c' est Ohrmazd, le dieu Créateur'. ${ }^{4}$ The doctrine is found not only in Pahlavi texts, Molé maintains, but also in the Avesta and even in the Gāthās. ${ }^{5}$

La divinité supreme offre le sacrifice pour créer le monde et établit par là un acte archétypique. Désormais tout sacrifice sera une re-création de l'univers, tout autel symbolisera le monde. Le monde sera maintenu par le sacrifice, chaque année sera renouvelée par le contact avec le Grand Temps opéré par le sacrifice. L' ouverture sur le Grande Temps abolira le present, confondra sur un plan unique le moment primordial de la création, le moment du sacrifice et celui de la Rénovation finale. ${ }^{6}$

2 Jean Kellens (1994), 10.

3 See Alberto Cantera (2013a), 43; (2013b), 107; (2016), 157.

4 Marijan Molé (1963), 125.

5 Marijan Molé (1963), 132-139.

6 Marijan Molé (1963), 132. 
I have argued in another article that the doctrine, especially 'le sacrifice de la création', is basically an application of Eliade's general theory of sacrifice and the so-called dialectic of the sacred and profane to Zoroastrianism. ${ }^{7}$ There is no evidence for it in Avestan texts, ${ }^{8}$ and the Pahlavi texts that have been adduced for the existence of such a doctrine do not bear it out. Molé's prime witness, a passage from the third chapter of the Bundahišn, is specious. ${ }^{9}$ This text has also been invoked by Skjærvø following Molé without examination, which is unfortunate, since it seems to be the mainstay of the doctrine. I look at it further below. Molé also cites another text in support of his theory, from chapter 16 of the Pahlavi Rivāyat, which is about the virtues of the Gāhāmbār ceremony and solid offering.

16b1 gyāg-ē paydāg kū zarduxšst az Ohrmazd pursīd kū hargiz az-it mēzd kard [b2] ohrmazd guft kū-m kard čè ka-m gēhān dād ā-m mēzd-ē be kard ka-m gyān ō gayōmard dād ā-m mēzd-ē be kard ka tō zardux̌̌t az mād zād hè $\bar{a}-m$ mèzd-ē be kard ka-t dèn az man be padìrift à-m mēzzd-ēbe kard mēzd èdōn sahīg (kū) mardōmān harw kār ud dādestān i frärōnīhā frāz kunēnd

7 Amir Ahmadi (forthcoming).

8 In a number of Yašts, we find Ahura Mazdā and Iranian heroes (and even villains), offering sacrifice to individual deities. In return, they ask the god for various 'favors', such as victory over enemies, gaining universal dominion, winning over a key figure, etc. These socalled 'catalogs of sacrificers' (e.g., Yašt 5.17-118) show the importance of sacrifice in the Avesta as the fundamental matrix of the relation of humans and gods. We could perhaps characterize the conception of sacrifice found in the 'catalogs' as a system of exchange of gifts. See Bernfried Schlerath (1986), 416-417; Stefan Zimmer (2009), 183-184. Sacrifice apparently invigorates Avestan gods. One may surmise from this that in, e.g., the Yašts, sacrifice is thought to help divine entities to carry out their regular roles. To take the further step, however, and assert that 1) these roles include cosmological functions, which 2) sacrifice makes possible, and that 3) sacrifice thereby maintains the cosmos is, in my opinion, one step too many. The existence in the Yašts of such a conception of sacrifice is yet to be demonstrated in situ. Perhaps both creation-by-sacrifice and maintenance-by-sacrifice are found in the Brāhmaṇas. See Sylvain Lévi (1898), 13-35; Thomas Oberlies (2012), 240 ff. In one version of the late Vedic account of Prajāpati's creation, the god creates ('emits' from $\sqrt{s a r j}$ ) the constituents of the world and ritual from his own body by practicing ritual austerities. The 'demonstrated' common origin is the basis of the supposed power of sacrifice. See Sylvain Lévi (1898), 22-24; Louis Renou (1968), 10. Thus Prajāpati is (the equivalent of) Brahman in the Śatapatha Brāhmaṇa. One must note that this is not the only Vedic account of creation. The most insistently articulated virtue of sacrifice in Brāhmaṇic literature is immortalization. See, for instance, Sylvain Lévi (1898), 17 and 27; Charles Malamoud (1996), 201-206, 214-225.

9 Marijan Molé (1963), 126. 
$\bar{a}-$ šān pad bun mēzd-ē be kunišn [b3] čè paydāg kū mēzd-ē pad sē mard ā-š bēwar frawahri $\bar{~}$ ašōwān be awiš rasēnd

16b1 (In) one place (it is) revealed that Zoroaster asked Ohrmazd: 'Did you ever make an offering?'

16b2 Ohrmazd said: 'I did (so), for when I created the world, then I made an offering; when I gave life to Gayōmard, then I made an offering; when you, Zoroaster, were born from your mother, then I made an offering. When you received the religion from me, then I made an offering. The offering is so worthy (that in) all duties and obligations that men perform righteously, they should start by making an offering.

${ }_{16} \mathrm{~b}_{3}$ For (it is) revealed that (when) an offering (is made) by three men, then 10,000 fravašis of the righteous come to it. ${ }^{10}$

The theme of the passage is the virtues of solid offering, and not creation through sacrifice. This is quite clear from the end of $b_{2}$ where the author urges the practice on the faithful. In order to make the point, he associates ritual offering with especially salient events in the mental landscape of a Zoroastrian. Whether or not in Zoroastrian tradition the god celebrates Zarathuštra's acceptance of the religion with a sacrifice-as far as I know this is an occasional story — one would hardly think of adducing this passage as a proof of its being a doctrine. It is no different for the ensoulment of Gayōmard or Zarathuštra's birth, or the creation of the world. There is no question in any of these events of the efficacy of ritual offering, which in fact takes place in each case after the fact. That Mazdā is known (from a number of Yašts ${ }^{11}$ ) to have performed sacrifices has suggested to, and provided the ground for, the author to invoke the example of the god for urging the practice on the faithful, with a view, of course, to priestly interests. ${ }^{12}$ This is the only Pahlavi text, aside from the passage from

10 The text and translation (slightly modified) are from Alan V. Williams (1990), vol. 1, 87-89 and vol. 2, 31, respectively. In Yašt 5 and 15 Ahura Mazdā offers sacrifice to Ardvī Sūrā Anāhitā and Vāyu, respectively. See Stig Wikander (1941); Norbert Oettinger (1983); Éric Pirart (2010).

12 Molés attempt to connect the priest's advice with his doctrine is unconvincing. 'Les hommes doivent agir comme Ohrmazd lui-même a agi; à tous les moments décisifs il a offert un myazd, et les hommes le font de la même façon. Les fravahr viendront les aider, les mêmes fravahr qui viennent en ce monde pendant les Fravartīkän. Tout sacrifice reproduit celui du dernier Gāsānbār, n' en est qu'un cas special ... Ohrmazd qui offre le myazd, à la creation, s' assure lui aussi le concours des fravaši' (Marijan Molé (1963), 127). Since the fravašis come to the righteous man's ritual offering, and since in making 
the third chapter of the Bundahišn, that Molé cites in support of the existence of the doctrine in Zoroastrianism.

Molé adduces the Bundahišn passage without actually citing it, and refers to the text in Zaehner's Zurvan, which is itself based on the edition of Anklesaria. Here is the text as it appears in Zurvan: 'Ōhrmazd apāk amahrspandān

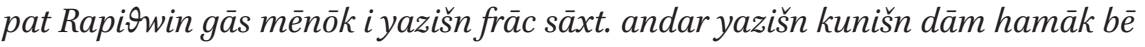
dāt (21) apāk bō̄ Fravahr i martōmān uskārt'.13 Zaehner's translation is: 'At the Rapi $\theta$ win time Ohrmazd and the Amahrspands fashioned the "idea" (mēnōk) of sacrifice. By the performance of sacrifice all creation was created. He took counsel with the consciousness and Fravahr of man.14 Skjærvø cites the same text to show that Mazdā creates the world through sacrifice. He removes the problematic bōy, however, without any comment: 'ohrmazd abāg amahrspandān pad rabihwin (gāh) mēnōy yazišn fräz sāxt andar yazišn kunišn dām hamāg bē dād abāg būd frawahr ì mardōmān ... At Midday, Ohrmazd together with the Lifegiving Immortals prepared the sacrifice in the world of thought. During the performance of the sacrifice, the entire creation was established. The fravashis of men were with him.' ${ }^{15}$ The rest of the Pahlavi text, which Skjærvø does not give, shows that the last sentence in his translation cannot be right, since it leaves uskārd 'consulted' stranded. Also, abāg requires an (indirect) object, which is missing in the Pahlavi text as he analyses it. The passage from the Bundahišn in Pakzad's critical edition reads:

3.26) Ohrmazd abāg Amahraspandān pad Rapihwin mēnōg ì yazišn frāz sāxt. u-š andar yazišn \{kunišn dām hamāg\} be dād abāg bōy ud frawahrīmardōmān uskārd udxradī harwisp-āgāh pad mardōmān frāz burd

such offerings the sponsor follows the example of the god, and since, according to Yašt 13, the god was helped in his creation by the fravašis, the god must have created through sacrifice, which explains why the fravašis were present at the creation of the world and helped.

13 Robert C. Zaehner (1972), 324.

14 Robert C. Zaehner (1972), 336. Unlike the fravaši, bōy or bōo, which Zaehner translates with 'consciousness' is not an unambiguously immortal component of the human person in Zoroastrian Pahlavi literature. It is the messenger between the (immortal) ruwān and the (biological) gyān, and tied to the senses. Thus its apparent presence in the primordial scene may be problematic.

15 Prods O. Skjærvø (2007), 57-58. The translation of the text, as he gives it, is problematic, which shows that the text is unreliable. In Pahlavi mēnōg very rarely means 'in the world of thought'; and in the first four books of the Bundahišn that I checked it never does, where either the adverb mēnōgīhā or the adverbial phrase andar mēnōgīh or pad mēnōg(īh) is used. See also Prods O. Skjærvø (2013), 313-314. 
ud guft kū kadār-tān sūdōmandtar sahēd ka-tān be ō gètīg brēhēnēm ud tanīgardīhā abāg druz be kōo $(x)$ šèd ud druz be abesīhēnēd u-tān pad frazām drust anōšag abāz wirāyēm u-tān abāz ō gètīg dahēm hamēìgīhā a-marg ud a-zarmān ud abē-hamēmāl bawēd ayāb-tān hamēšag pānāgih az èbgat abāyēd kardan.

3.27) u-šān dìd pad ( frawahr ìmardōmān) ān xrad ı̀ harwasp-āgāhīh anāgīh az druz ud Ahreman andar gètīg padiš rasēd ud abdom abè-hamēmālīh az petyārag ud drust ud anōšag abāz-bawišnīh pad tan ı̄pasēn tā hamēe(w)ud-hamē(w)-rawišnīh rāy pad šudan ō gètīg ham-dādestān būd hēnd. ${ }^{16}$

The phrase in curly brackets is given differently in K20, K20b, M51: harw abzār pad ōzadan ìpetyārag abāyist, which I prefer for reasons that become apparent. Here is the translation:

Ohrmazd together with the Amahrspandān made the Spirit of Sacrifice in Rapihwin (period), and during the sacrifice he created \{all the means necessary for smiting the adversary\}, and consulted the fravašis and perceptions of humans, and inspired humans with the all-knowing intelligence and said thus: which (choice) seems more beneficial to you: that I dispatch you to the corporeal (world), and you struggle with the Lie in person, and destroy the Lie, and in the end I reconstitute you complete (and) immortal, and send you back to the corporeal (world) forever deathless and timeless, and you will be without adversary, or that you perpetually need protection from the assault (of Ahriman)?

And, by means of that all-knowing intelligence, the fravašis of humans saw that harm will come to the corporeal (world) from the Lie and Ahriman and (saw) the final release from the adversary, and (saw) the restored life, perfect and immortal, in the final body, extending forever-and-ever, and were all agreed to go to the corporeal world.

One can see from the passage that at issue is the decision of the fravašis in the face of Ahriman's pending assault. Chapter 3 ends with this theme and the following chapter is called abar dwāristan ì $\bar{b} g \bar{a} t \bar{o}$ dām 'on the onslaught of (Ahriman's) assault on creation'. More importantly, there cannot be a question of 'creation through sacrifice' in the passage. In the first chapter of the Bundahišn, 
Mazdā creates the entire world in the realm or state of thought (dāmìgètīg ìpad $m \bar{e} n \bar{g} \mathrm{~d} \bar{a} d)$, nurtures it as an embryo in himself, ${ }^{17}$ and finally creates the world in corporeal state (dām-dahišnīh i gètīgìha $)$. Chapter two gives further details about the creation of the heaven and celestial bodies. The third chapter is about the justification and preparation for the struggle against Ahriman (abar čiyōn ud čim dahišnīh ì dām ò ardīkkarīh). Each of the Amahrspandān takes charge of one of the elements of the creation in the struggle against Ahriman and his horde (3.12-22). And 'innumerable other (guardian) spirits for the created world are appointed to help them [i.e., the Amahrspandān]' (3.23). Ohrmazd divides the day into five periods, and for each period appoints a guardian spirit ( harw hangām-ềw mēnōg-èw padiš gumārd), each being helped by a god, 'since he knows that when the assault (of Ahriman) comes, the day will be divided into these five periods' (3.24-25). Thus, there can hardly be a doubt that the passage (3.26-27) does not and cannot mean what Molé and Skjærvø purport. The world has already been created when Ohrmazd creates the 'spirit of sacrifice' and, in the company of the Amahrspandān, celebrates a sacrifice. Even if we cannot be absolutely certain that the purpose of this sacrifice is to prepare the means for dealing with the pending assault, the context of the sacrifice makes it absolutely certain that that purpose cannot be the creation of the world. The fact that there is no other Pahlavi text that suggests a 'cosmogonic sacrifice' adds to the force of our argument. Also note that there is no mention in this passage of the ahuna vairiia, whose primordial recitation by the creator is for the advocates of the 'doctrine' the cosmogonic sacrifice.

Molé, Skjærvø and Cantera seem to rely on the Young Avestan commentary (Y 19) on the ahuna vairiia in their views about the meaning of Zoroastrian sacrifice and in particular about cosmogonic sacrifice. Zoroastrian liturgy presents a cosmic drama whose first act is a cosmogonic sacrifice, which they see behind Mazdā's primordial recitation of the ahuna vairiia. But their casting of the ahuna vairiia in the cosmogonic role (the 'cosmogonic recitation of the ahuna vairiia', to use Kellens's expression) has been done without any justification. They have simply assimilated the formula to the 'doctrine'. Kellens alone has tried to give a justification. According to his interpretation of Y 19, the supposed world-creating sacrifice involved the recitation of the ahuna vairiia and the presence of certain gods and Zarathuštra or, being understood, his fravaši. I have made a number of critical observations about his views. ${ }^{18}$ Kellens's inter-

\footnotetext{
17 See Fazlollah Pakzad (2005), 25: Ohrmaz pad dām-dahišn̄̄h mādarīh ud pidarīh ̄̇ dahišn ast čè ka-š dām pad mēnōg parward ān būd mādarīh ka-š be ō gètīg dād ān būd pidarīh.

18 See Amir Ahmadi (2013).
} 
pretation of Y 19 is premised on a questionable analysis of the verbal phrase para cinasti. ${ }^{19}$ According to Y 19.2, 4 and 8, Ahura Mazdā recited the ahuna vairiia after the creation of aməșa- spəṇta- and prior to the creation of the cosmos. Aside from this relative chronology of the recitation of the ahuna vairiia, which obviously places the latter in primordial times, there is the enigmatic Y 19.15 which seems to be the Avestan precedence of the account in Pahlavi literature (1.28-31) of the confrontation of Ohrmazd and Ahriman at the end of the first cosmic period. The Bundahišn (1.28 to 31) version is as follows.

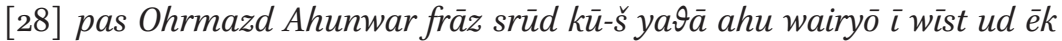

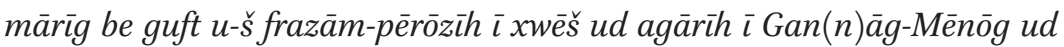

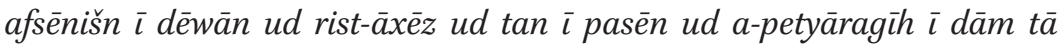
hamē(w)-ud-hamēe(w) rawišnīh be ō Gan(n)āg-Mēnōg nimūd. [29] Gan(n)āg-Mēnōg ka-š agārīh ì xwēš ud afsēnišn ı̀ dēwān hāmist dìd stard ud a-bōy būd abāz ō tam ōbast. [30] ôwōn čiyōn pad dēn gōwēd kū ka-š sēe èk-ēew) guft būd Gan(n)āg-Mēnōg az bìm tan andar hanǰ̀d. ka-š dō bahr guft būd Gan(n) āg-Mēnōg pad šnūg andar ōbast. ka-š bowandag guft būd agār būd Gan(n)āg-Mēnōg az anāgìh pad dāmān ì Ohrmazd kardan. [31] sē hazār sāl pad stardīh sayist. ${ }^{20}$

Then Ohrmazd recited the ahuna vairiia: he said the twenty-one-word ya $\vartheta \bar{a}$ ahu wairyō and (thereby) showed Ahriman his own final victory and the impotence of Ahriman and destruction of the Dēwān and the resurrection of the dead and the final body and the freedom of the world from adversity extending forever-and-ever. [29] When Ahriman saw his own impotence and the destruction of all the Dēwān, he became unconscious and fell back into the darkness. [30] It is stated as follows in the religion: when a third of it was said Ahriman withdrew in fear. When two thirds of it was said Ahriman fell on his knees. When all of it was said Ahriman

19 'Je fais donc l'hypothèse que ciš, avec para, signifie "poser en doctrine que acc. appartient à dat., préalablement", voire "poser en doctrine que acc. est préalable à dat."' (Jean Kellens (2010), 38). Cantera too points out the importance of Kellens's analysis of the verbal phrase for his interpretive frame: '[h]is understanding of the three commentaries [i.e., Y 1921] ultimately depends on his interpretation of para cinasti as expressing a relationship of dependence and anteriority. Through para cinasti, the author [of the commentaries] established a cosmogonic succession that is the basis for a hierarchy in sacrificial dignity' (Alberto Cantera (2016), 157). See Amir Ahmadi (2013), 12-14 for my criticisms of Kellens's analysis. 
became incapable of harming Ohrmazd's creatures. [31] (He) laid unconscious for three thousand years.

The Wizìdagìhà $\mathbf{\imath} \bar{a} d s p r a m$ (1.12 to 25) gives a philosophically expanded version of the same account:

Ohrmazd dìd kū ka Ahreman parwastag kardan nē šāyēd hamē ka xwāhèd

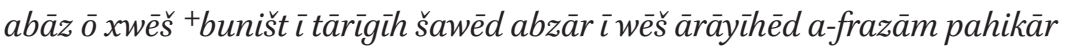
bawēd $u$-š pas az zaman ${ }^{+} k a r d a n$ ahunawar fräz srüd. (13) u-š pad ahunawar sē èwēnag awišnimūd. (14) fradom kū har tis ān fräron $\{\bar{\imath}\}$ Ohrmazd

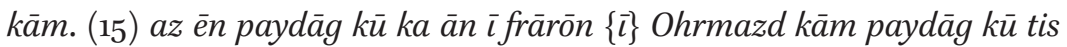

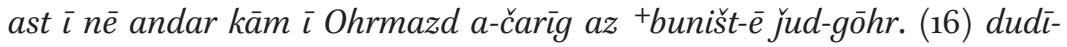
gar èn kū kē ān kunēd ì Ohrmazd kām ā-š mizd ud pādāšn xwēšrig. ōy

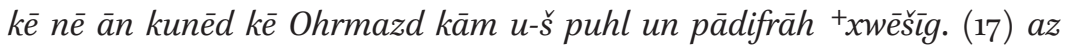
èn nimāyūhēd kirbakkarān mizd ud wināhgārān pādofrāh ud mādayān $\bar{\iota}$ wahišt ud dušox az-iš wizārīhēd petyāragōmandīh. (18) sidīgar nimūd kū

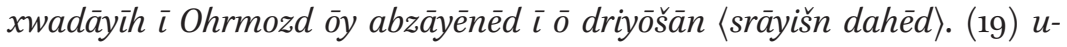
š nimūd kū ast-xīrān ō niyāzig-xīrān ayār bawišn čiyōn āgāh-dahišnān ō an-āgāhān hammōxtan tuwānīg-xwāstagān ō niyāzìg-xwāstagān rādīhā ${ }^{+}$dādan ${ }^{+}{ }^{+} x w a d+$ frayād-dastīh $\overline{~ O h r m a z d ~ d a ̄ m a ̄ n ~ e ̀ k ~ o ̄ ~ d i d ~ a n d a r ~ k o ̄ x s ̌ i s ̌ n ̃ ~}$ ardīg. (20) čiyōn frašgirdārīh pad èn sē tis šāyèd büdan. (21) ast fradom rāst-dēnīh ìxwad āstawānīh ı̄abar dō-+buništīh pad ān ristag ud brahm kū Ohrmazd hamāg wehīh ud a-wattarīh u-š kām wisp frārōn. Ahreman wisp wattarīh ud a-wehīh. (22) dudīgar èmēd ì mizd $\langle u d\rangle$ pādāšn ì kirbakkarān

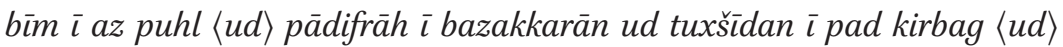
pahrēxtan ì az wināh. (23) sidìgar ham-ayārīh +būdan ì dāmān èk abāg did ud az ham-ayārīh ham-spāhīh az ham-spāhīh pērōzīh ì abar dušmen bawēd $\bar{\iota}^{+} x w a d$ frašgird. (24) pad èn gōwišn stard būd abāz ō tam ōbast. (25) Ohrmazd dām tanōmandīhā be ō gètīg dād fradom āsmān dudīgar āb sidīgar zamīg čahārom urwar ud panjom gōspand šašom mardōm ud ātaxš andar wisp būd pargandag hāmist pad šaš gōhrag ì har gōhrag-ēe

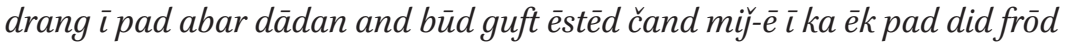
nihēnd. ${ }^{21}$

Ohrmazd realized that when it was not possible to encircle Ahriman(for) each time he wanted he would plunge to the bottom of darkness (and) organize more weapons - the battle would become endless, and

21 Philippe Gignoux \& Ahmad Tafazzoli (1993), 32. 
(so) after establishing the (limited) time he recited the ahuna vairiia, (13) and by means of the ahuna vairiia showed Ahriman three kinds (of things). (14) First: whatever is righteous is the will of Ohrmazd. (15) It is evident from this that if whatever is righteous is the will of Ohrmazd, it is obvious that what is not in the will of Ohrmazd (is) inevitably from a fundamentally different substance. (16) Second this: whoever does what is the will of Ohrmazd appropriates reward and compensation. He who does not do what is the will of Ohrmazd appropriates expiation and punishment. (17) Thus is demonstrated the reward of the virtuous people and the punishment of the sinners, and the raison d' être of paradise and hell, by which is settled (the matter of) hostility (to the will of Ohrmazd). (18) Third, (Ohrmazd) showed that he who gives protection to the needy contributes to the lordship of Ohrmazd (19) and showed that those who possess things should help those who need things, just as the knowledgeable should instruct the ignorant, (and) the rich should generously give to the poor, which is itself the mutual assistance of the creatures of Ohrmazd in the zealous struggle (against Ahriman). (20) For the final restoration will be possible by these three things: (21) The first is being of the right religion, which is itself the profession of two fundamental principles in this way and manner: Ohrmazd is completely good and free from any badness and his will is wholly righteous; Ahriman is all evil and without any goodness. (22) Second: the hope of virtuous people for reward and compensation (and) the fear of expiation and punishment in evil-doers, and striving for virtuous deed and guarding against sin. (23) Third, the creatures' being mutually helpful, and from mutual assistance (comes) common fighting, and from common fighting will result victory over the enemy, which is itself the final restoration. (24) With this announcement (Ahriman) became unconscious and fell into the dark depths. (25) Ohrmazd created the world in body in corporeal state: first the sky, second, the waters, third the earth, fourth the plants, fifth the domestic animals, sixth humans, and the fire was in everything, spread everywhere, all (consisting) in six substances, the creation of which each took as much time, it is said, as the blink of an eye.

There are a number of noteworthy points in these two passages. First of all, the purpose of the ahuna vairiia, or rather its recitation, is to remove the adversary, be it temporarily, so that creation of the world can proceed. We can see this from the end of the passage cited from Zādspram (24 and 25). It is even more explicitly stated in the Bundahišn (1a.2): andar ān agārîh ì òy Gan(n)āg-Mēnōg Ohrmazd dām ō gètīg brēhēnìd 'during Ahriman's impotence, 
Ohrmazd fashioned the creation in corporeal state..22 The recitation of the formula is instrumental in the creative process only insofar as it removes the obstacle that the adversary would have posed; it has no creative function. Nowhere in these passages, which are after all about creation, is it said that Ohrmazd created the world (whether in mental or in corporeal state) by way of a sacrifice. The sequence of the events is 1) Ahriman's appearance and confrontation, 2) recitation of the ahuna vairiia by Ohrmazd, 3) Ahriman's unconsciousness or impotence resulting from the recitation, 4) Ohrmazd's creation..$^{23}$ The apparent power of the recitation consists in making known to Ahriman the final outcome of the confrontation. It imparts eschatological knowledge and (thereby) achieves eschatological victory. This is a fundamental point. One can hardly overemphasize the eschatological orientation of the the ahuna vairiia and its essentially evil-destroying nature. Its function is not to create but to destroy (evil). Creation can proceed thanks to the obstacledestroying power of the ahuna vairiia.

The recitation of the ahuna vairiia seems to have the same significance in Y 19 that the later (Pahlavi) Zoroastrian tradition ascribes to it. It is the foremost weapon in the struggle against Ahriman and his creatures. In the Bundahišn, Mazdā recites it at the close of the first period of three thousand years and induces unconsciousness in his enemy for almost the entirety of the second period. As we saw, the reason given in the Pahlavi account for the anti-demonic efficacy of the 'twenty-one-word' text is that by reciting it Mazdā 'showed' (nimūd) Ahriman the triumphant restoration of the good creation. It is certainly not a means of cosmological ordering. It may be an arguable point that the recitation of the formula was generally thought to possess an eschatological power in its own right, especially because it epitomizes the Dēn, whose raison d'être, just like the good creation itself, is the destruction of Mazdā's enemy. In other words, its cognitive aspect may not be essential to its functioning, but in Pahlavi texts at least its primordial recitation consistently possesses the cognitive aspect. For instance, there is the following passage in the Bundahišn that places the ahuna vairiia in the primordial context. Ohrmazd, it says, 'fashioned forth' ( fräz brēhēnìd) the 'fire-body' or 'fire-form' (āsrō-kerpa) from the 'endless light' (asar-rōšnīh), and 'created the whole creation in fire-form [i.e., in a body consisting of fire]' (dām-iz hamāg andar āsrō-kerpa be dād). Then the 'spirit'

22 Fazlollah Pakzad (2005), 26.

23 The two accounts agree regarding the essential features. In the Bundahišn, creation takes place in two stages, and the creation of the finite time (zamān $\bar{\iota}$ dagrand-xwadāy) takes place in the first stage, while in Zādspram the finite time is created before the recitation of the ahuna vairiia. But these differences are not relevant for the argument. 
of the ahnua vairiia arises from the 'fire-form': az āsrō-kerpa Ahunwar frāz büd

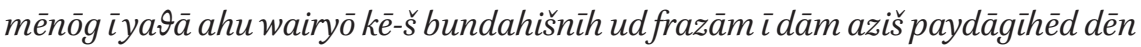
čiyōn dēn abāg dāmdahišnīh dahīhast 'from the fire-form arose Ahunwar, the spirit of ya $\vartheta \bar{a}$ ahu wairyō, by whom is revealed the primal creation and the end of the created world, (the formula is) Dēn, for the Dēn is created at the same time as the creation of the world' ${ }^{24}$ The 'spirit' of the primordial formula personifies the knowledge of the beginning and the end of the world; and the formula is equated with the Dēn or contains the Dēn in miniature, because the latter is comprehensive and perfect knowledge, coeval with the world.

When we turn to Y 19, we find very similar ideas. The eschatological valence of the ahuna vairiia is explicitly stated in Y 19.6, 7,10 and $11 .{ }^{25}$ The recitation of the ahuna vairiia takes place in the Avestan text, too, before the process of creation (Y 19.2, 4 and 8). The text is clear on this point. One should think that if the Young Avestan exegete meant to say that Mazdā created by way of a sacrifice or during a sacrifice, he would not have said that the god created after reciting the ahuna vairiia. It seems that even the circumstance and the purpose of the recitation in the Avestan text are similar to those stated in the Pahlavi texts cited above, namely the confrontation of Ohrmazd with Ahriman and the god's recitation of the formula in order to incapacitate the latter.

Y 19.15

vahištō ahurō mazdå ahunəm vairīm frāmraoț

(vahištō hāmō kāraiiat

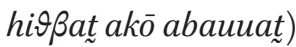

aṇtaraca druuaṇtom āmrūta aiia aṇtara.uxti

nōit nā manå nōit sayha nōit xratauū̄

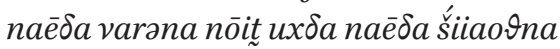

nōit daēnå nōit uruuąō hacinte

Divine Ahura Mazdā pronounced the ahuna vairiia (the divine one organized everything; the evil one became bound ${ }^{26}$ ) and banished the Parti-

24 Fazlollah Pakzad (2005), 21. Although the syntax of the relative clause (kē-š bundahišnīh ud frazām ¿̀ dām aziš paydāgīhèd dēn) is somewhat convoluted, it is analyzable, and its meaning is clear. The relative clause contains a parenthetical clause. $k \bar{e}$ refers to the formula, and not the 'spirit'; the enclitic possessive refers to the 'spirit', taken up by aziš 'by whom' in the nested clause.

25 See Amir Ahmadi (2013) for elaboration.

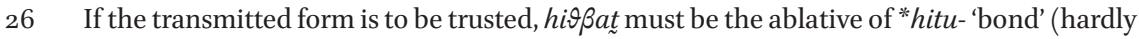


san of Deceit with this interdiction: 'Neither our minds, nor our pledges, nor our wills, nor our choices, nor our speeches, nor our acts, nor our visions, nor our souls associate'.

Y 19.15 must have been a kind of epilogue to the close exegesis of the ahuna vairiia that precedes it (Y 19.12-14) - without the two short statements that I have placed in brackets. These were added as a further description of the circumstance in which the two protagonists had to be imagined. They are in the same didactic, staccato style as the catechism that follows and constitutes the rest of Y 19, which is clearly a different layer. They are also grammatically defective, like the catechistic section. In any case, the duplication of vahišto shows the two lines are a later insertion. ${ }^{27}$ What is important is that just as

Gāthic hi̊u- 'companion') from $\sqrt{h i}$ 'bind'. The ablative is used in the Avesta for both point of departure and (less frequently) point of arrival.

27 The analysis Kellens gives of the text is not convincing. See Jean Kellens (2010), 44-45. Here is his translation: 'Ahura Mazdā (était) très bon (lorsqu'il) a recite l'A huna Vairiia. (Il était) très bon (lorsqu') il lui a donné une organization-parfaite. (Il était) mauvais (lorsqu') il est sorti d'amitié et a adressé au Trompeur cette declaration de rupture', etc. As far as I can see, Kellens's translation requires in the Avestan text the addition of a relative clause in yat 'when' or an adjectival phrase describing the subject of the verbal phrase for each of the two sentences; it aims to extract a plausible meaning from the text, but without success.

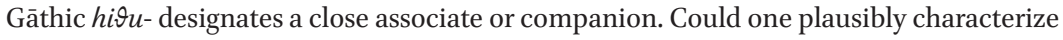
the relation of the god with his antagonist as 'friendship' prior to his 'leaving' it? The complement in ablative with $\sqrt{a}$ h 'be' can have the sense of origination (ablativus originis), not necessarily a genetic one. It can describe, for example, the intellectual lineage of the subject. See Amir Ahmadi (2016). One might think that it could convey the same sense with $\sqrt{b u}$ 'become'. But if so, the complement could hardly be something that the subject abandons. There is also the problem of describing Mazdā as 'bad'. Kellens argues that this is not 'an absurdity' since 'se montrer aka envers le draguuant est un merit (Y 33.2, 47.4 et 51.8)' (Jean Kellens (2010), 44). (In Y 47.4, it is actually the supporter of the partisan of druj that is designated as $a k a-$.) In Y $51.8 a k a$ - is used in opposition to $u s ̌ t i-$ : whereas the supporter of ašòa can look forward to being fulfilled after death, the partisan of druj should only expect misfortune ( $a k a-)$. In Y 33.2 it is said that whoever does harm $(a k a-)$ to the partisan of druj with his thought, speech and hands satisfies Mazdā. Doing harm to the (supposed) enemies of Mazdā wins his approbation. But this can hardly make describing the god as 'harmful' or 'bad' when he 'leaves friendship' understandable. One could, if needs be, understand describing what Mazdā does to the partisan of druj as 'bad' or 'injurious', but not designating the god as such. Doing 'bad' to the 'bad' is one thing, being 'bad' is another. In the Avesta, as a characterization of agents, aka-exclusively designates reprobate beings, and is used almost exclusively of evil divine agents. This is also the case when it is used as a qualification of thought or speech 
in the Pahlavi texts the setting of the (ritual) recitation of the ahuna vairiia in Y 19.5 is the confrontation of the god with his rival before creation gets underway, and its purpose is the removal of the latter. That this is the virtue that was ascribed to the formula in the Avesta is also evident from Yt 19.81 where Zarathuštra is said to have driven the daêuuas underground by reciting it. Thus, there cannot be any reasonable doubt that as far as Zoroastrianism is concerned the ahuna vairiia has no cosmogonic function; its primordial recitation by the creator god does in no way imply a 'sacrifice de la création'.

Zoroastrianism like all (ancient) religions revolves around ritual, perhaps even more so than many others. It has a ritual for many an occasion, from the most banal to the most important events of life. Of course, in raising the profile of ritual in doctrine and subjecting all aspects of social life to it in practice, the clergy looked to its own elevation and empowerment. It so happened that in Iran this same class was by and large the custodian of cultural products. It is not surprising then that this ritual-centeredness is extended in myth. The Yašts are an eloquent testimony to this. ${ }^{28}$ But must the highly privileged status of sacrifice be due to its (supposed) cosmogonic or cosmological function? The proponents of a Zoroastrian 'cosmogonic sacrifice' should explain the formidable contradiction between its (supposed) constitutive status and the lack of evidence for it in the sources. In my mind, it is not a coincidence that these same scholars insist on reading the Zoroastrian liturgy, in Cantera's words, 'as a coherent text and authentic ritual'. ${ }^{29}$ The ritual, whether the Gāthās or Yasna or Vīdēvdād, stages a drama with a beginning and an end: both creation and final restoration takes place through sacrifice. In this, too, they have followed Molé.

Tandis que l'Ahunwar est lié aux débuts, et que sa recitation fait partie de l' acte créateur de l'univers, la prière Airyamā išyō qui clôt la collection est intimement liée aux événements des derniers jours, à la Rénovation de l' existence. ${ }^{30}$

or action. The agent who is $a k a$ - is 'bad' tout court; the mind that is $a k a$ - is 'bad' tout court.

28 Cf. Antonio Panaino (2016).

29 Alberto Cantera (2016), 148.

$30 \quad$ Marijan Molé (1963), 143. Cf. Prods O. Skjærvø (2007), 64-83; Alberto Cantera (2013b), 107108. 


\section{References}

Ahmadi, Amir (2013). "Y 19 manas.paoiriia- and aṣ̌a.paoiriia-." Iranian Studies 46: 863876.

Ahmadi, Amir (2016). "Avestan ciЭra-." Dabir Journal 3.

Ahmadi, Amir (forthcoming). "A Gāthic Rite? A Critique of the Cosmological Interpretation of the Gāthās." Iranian Studies 502.

Cantera, Alberto (2013a). The Old Avestan Texts in the Videvdad and Visperad Ceremonies. Le sort des Gathas et autres études iraniennes in memoriam Jacques Duchesne-Guillemin. É. Pirart. Leuven-Paris, Peeters: $25-48$.

Cantera, Alberto (2013b). "Talking with God: The Zoroastrian Ham.parsti or Intercalation Ceremonies." Journal Asiatique 301: 85-138.

Cantera, Alberto (2016). "A Substantial Change in the Approach to the Zoroastrian Long Liturgy: About J. Kellens's Études avestiques et mazdéennes." Indo-Iranian Journal 59: 139-185.

Gignoux, Philippe \& Ahmad Tafazzoli (1993). Anthologie de Zādspram. Leuven-Paris, Peeters.

Kellens, Jean (1994). Chaire de langues et religions indo-iraniennes. Leçon inaugurale. Paris, Collège de France.

Kellens, Jean (2010). Études avestiques et mazdéennes. vol. 3. Le long préambule du sacrifice. Paris, De Boccard.

Lévi, Sylvain (1898). La doctrine du sacrifice dans les Brāhmaṇas. Paris, Ernest Leroux.

Malamoud, Charles (1996). Cooking the World. Delhi, Oxford University Press.

Molé, Marijan (1963). Culte, mythe et cosmologie dans l'Iran ancient. Le problème zoroastrien et la tradition mazdéenne. Paris, PUF.

Oberlies, Thomas (2012). Der Rigveda und seine Religion. Berlin, Verlag der Weltreligionen.

Oettinger, Norbert (1983). Untersuchungen zur avestischen Sprache am Beispeil des Ardvīsūr-Yašt. Habilitationsschrift. Erlangen, Universität Erlangen-Nürnberg.

Pakzad, Fazlollah (2005). Bundahišn: Zoroastrische Kosmogonie und Kosmologie. Tehran, Centre for the Great Islamic Encyclopaedia.

Panaino, Antonio (2016). Zoroastrismo: Storia, temi, attualità. Brescia, Morcelliana.

Pirart, Éric (2010). Les Adorables de Zoroastre. Paris, Max Milo.

Renou, Louis (1968). Religions of Ancient India. New York, Schocken Books.

Schlerath, Bernfried (1986). Opfer. Wörterbuch der Mythologie. Band IV: Götter und Mythen der kaukasischen und iranichen Völker. H.W. Hausig. Stuttgart, Klett-Cotta.

Skjærvø, Prods O. (2007). The Avestan Yasna: Ritual and Myth. Religious Texts in Iranian Languages. F. Vahman and C.V. Pedersen. Copenhagen, Det Kongelige Danske Videnskabernes Selskab: $57-84$.

Skjærvø, Prods O. (2013). Afterlife in Zoroastrianism. Jenseitsvorstellungen in Orient. P. Bukovec \& B. Kolkmann-Klamt. Hamburg, Verlag Dr. Kovač: 311-349. 
Wikander, Stig (1941). Vayu. Texte und Untersuchungen zur indo-iranischen Religionsgeschichte. Teil 1: Texte. Uppsala-Leipzig, Harrassowitz.

Williams, Alan V. (1990). The Pahlavi Rivāyat Accompanying the Dādestān ì Dēnīg. 2 Volumes. Copenhagen, Det Kongelige Danske Videnskabernes Selskab.

Zaehner, Robert C. (1972). Zurvan: A Zoroastrian Dilemma. New York, Biblio \& Tannen Publishers.

Zimmer, Stefan (2009). “'Sacrifice' in Proto-Indo-European.” The Journal of Indo-European Studies 37: 178-19o. 